University of Arkansas, Fayetteville

ScholarWorks@UARK

University Libraries Faculty Publications and

Presentations

University Libraries

Summer 2013

\title{
A Tale of Two Counties: How Two School Libraries in Rural Western China Serve Local Needs
}

Wei Zhipeng

Jiang Guodong

Niu Tuowen

Tim Zou

University of Arkansas, Fayetteville, tzou@uark.edu

Elaine Dong

Follow this and additional works at: https://scholarworks.uark.edu/libpub

Part of the Collection Development and Management Commons, and the Information Literacy Commons

\section{Citation}

Zhipeng, W., Guodong, J., Tuowen, N., Zou, T., \& Dong, E. (2013). A Tale of Two Counties: How Two School Libraries in Rural Western China Serve Local Needs. University Libraries Faculty Publications and Presentations. Retrieved from https://scholarworks.uark.edu/libpub/16

This Article is brought to you for free and open access by the University Libraries at ScholarWorks@UARK. It has been accepted for inclusion in University Libraries Faculty Publications and Presentations by an authorized administrator of ScholarWorks@UARK. For more information, please contact scholar@uark.edu. 


\title{
A Tale of Two Counties: How Two School Libraries in Rural Western China Serve Local Needs
}

\author{
Wei ZHIPENG 魏志鹏, JiAng GUODONG 蒋国栋, NiU TuOWEN \\ 牛托稳, Tim Zou 邹际平, AND ElAINE DONG 董小芬
}

\begin{abstract}
This report presents a case study of school library programs in two rural counties in Western China. Since 2002, the libraries of Tianzhu and Tongwei high schools have undertaken a series of outreach initiatives to improve local residents' access to information and to address their cultural and educational needs. Over the past decade, both school libraries have played a leading role in improving the quality of life and enhancing the information literacy of local residents. Tianzhu No. 1 High School Library 天祝一中图书馆一which serves a large Tibetan and other minority populations- - has gained a reputation for its oral history of local culture program. This program trains students to conduct interviews with folk artists and scholars and then post their audiovisual recordings on websites. Tongwei No. 1 High School Library 通渭一中图书馆 is known for providing health care information through both in-person workshops and online. Recently, it implemented a tutoring service aimed at teaching residents to use online resources. These programs have been successful and sustainable in part because of the sponsorship and funding of the U.S.-based Evergreen Education Foundation (EEF) 美国青树教育基 金会. This report analyzes the results of these major initiatives, both of which do a great deal to reach out to rural residents, particularly farmers and the elderly.
\end{abstract}

\section{INTRODUCTION}

Digital communication and Internet connectivity have become indispensable tools for those who reside in economically developed countries. Through the Internet, we are more connected than ever, across wide geographical distances. A person with access to the Internet is likely to have several e-mail accounts and to be part of a multiple online social networks. 
For instance, the authors of this report live far apart from each other and have never met in person. Yet, as members of the China Evergreen Library Service community, they have communicated frequently via e-mail, Skype, and QQ. Internet communication and connectivity facilitate crosscultural, cross-border interactions in ways that people could hardly have imagined two decades ago. The impact of new communication methods is so significant that a business operation with global ties must leverage the emerging technology to retain its competitive edge. With the necessary convergence of global and local communities and the infusion of different socioeconomic contexts, communities are inevitably affected and reshaped through the process of "glocalization"-the localization of global communication and interaction.

\section{LiterATURE REVIEW}

Sociologists argue that spatiality is necessarily the condition of social interaction: people are more likely to develop relationships if they share "foci" such as workplaces, neighborhoods, and voluntary organizations where "joint activities are organized" (Feld, 1982, pp. 797, 799). In the pre-Internet era, most forms of social organization and activities were preconditioned on spatiality and proximity. Even today, social ties are formed locally because of time constraints and the ease of face-to-face interaction. Outreach is the only effective way to connect libraries to geographically dispersed rural communities. In the United States, support for library and information services in rural communities is provided through the outreach activities of national and state information agencies and local public libraries (Boyce \& Bert, 1995). Librarians in rural communities are often passionate about offering services to address local needs, such as reading programs for children, and individualized services for youth, the elderly, and their families. Ristina (1995, pp. 88-111) notes that the following elements are needed for the development of a rural library service plan:

- More attention to the specific needs of rural children

- Analysis of the impact of poverty on children using libraries in rural communities

- Creation of national networks, which allow rural librarians across the country to learn from each other

- Effective ways to provide professional knowledge about new developments in library service to rural libraries

- The development of methods that achieve better documentation of service to children (and adults) in rural communities

- Adaptation of planning methods for use in one-person libraries

- The creation of clear, simple manuals which outline services to young people

- Publicity about resources that already exist 
- National grant projects which enhance and highlight service in rural areas

- Increased attention to rural libraries in national publications, forums, etc.

- Increased support for librarians in rural communities that will be of benefit to both children and adults who use the nation's rural public libraries

When Ristina called attention to these specific needs, information was still largely disseminated in print format. Methods for reaching out to dispersed small communities tended to be constrained geographically. But then the Internet began to penetrate all aspects of our social and economic life. It is estimated that since the late 1990s, "traffic on the public Internet [has grown] by 100 percent per year" ("Internet," n.d.). The population of Internet users has grown exponentially. The widespread availability of Internet connectivity has reshaped the forms of our social interaction. Information and communication technology has helped to create a sense that we live in a smaller and interconnected world. ICTs also help dissolve social, cultural, and geographical boundaries (Taylor \& Latour, 2009).

The Internet offers an unprecedented opportunity for people to access a world of information (Uimonen, 2003, p. 281). It also enables people to establish transnational connections on a daily basis. Consequently, it enables "interplay between local-regional-global interactions," a powerful process that is often referred to as glocalization (Willems and Bossu, 2012, p. 186). In the specific context of this report, we observe that the globalization process has significantly facilitated a transnational collaboration between an NGO in the United States and schools in Western China. The Internet not only makes instant transglobal contact possible, it also offers a cost-effective way for a nonprofit organization to do business with seriously underfunded public schools. Chen and Wellman (2009) argue that the convenience and speed with which "information and interaction ... transcend geographic boundaries" (p. 526) is the most revolutionary effect of the Internet. Additionally, the Internet offers an ideal means of support for the grassroots model of service advocacy that shapes the work of the Evergreen Education Foundation 美国青树教育基金会 (EEF), an organization whose goal is to create and expand learning communities by establishing ties with school libraries.

Last, we need to recognize the effect of interplay in the dual processes of globalization and localization, which, thanks to the global connectivity, have become "prominent features of the contemporary complex societies" (Uimonen, 2003, p. 276). This phenomenon is neatly captured by the term glocalization, which we borrow from the jargon of anthropology (Taylor \& Latour, 2009). It is our contention that EEF's rural library service model is not like Apple's products-designed in the United States 
and manufactured in China. Instead, in this alternate model, ideas conceived in the United States are adapted in China. As a result, the balance tips more toward the process of localization, both in terms of developing social capital and utilizing technology.

\section{Methodology}

This report, as its title suggests, tells stories about the EEF through two library projects implemented at two EEF flagship schools. The approach used for our analysis is empirical, although data from two small surveys are included to illustrate our discussion. Descriptive evidence and feedback from library users and school administrators are also used wherever they fit. In succeeding sections, we describe the plans, implementation, and outcome of these projects chronologically. Our description documents the ways in which the project's implementers, the library staff, and volunteers worked and communicated throughout the process. The use of technology and the Internet were two important factors of the case studies. However, an assessment of their impact was not the primary focus of this report. As we point out in a later section, an "online sometimes, offline most of the time" communication mode operates in small rural communities, where personal ties and bond are the assurance for getting work done. "Face-time" and the "human moment" are still the preferred ways of communication. Online "face-time" — via Skype or QQ-might be a feasible way through which EEF officials could meet Chinese librarians, but it is not rural librarians', students', or community users' preferred mode of communication.

\section{EEF's China Rural Library Service}

The EEF is a U.S.-based nonprofit organization founded by Chinese and American professionals and academics in 2001. Seed money was provided by Mr. Richard Hsin 辛德俊, a Hong Kong entrepreneur and philanthropist. Its mission is to enhance educational opportunities in rural China in three ways: 1) by providing approximately 200 scholarships to financially disadvantaged students every year; 2) by expanding schools' and libraries' capabilities to add value to local communities, and facilitating information- and resource-sharing in schools and communities through new technologies; and 3) by advancing knowledge and understanding through conferences and workshops (Evergreen Education Foundation, http:// evergreeneducation.org/index.php).

The EEF is not the only nongovernmental organization (NGO) that sponsors community libraries in China. At the end of the 1980s, a few NGOs started sponsoring community libraries in China. By the end of 2010, the number of total domestic and overseas NGOs working in this area had reached fifty-one. The majority of these NGOs sent one-time donations of money, books, or supplies to community libraries. They stayed 
away from making long-term commitments to the libraries' development or management (Qiu \& Wang, 2011). The EEF is one of the few NGOs that pledged long-term support to its partner libraries.

In 2001, the EEF entered into partnerships with selected high schools in the underdeveloped northwestern provinces of Qinghai 青海 and Gansu 甘肃 and in the southwestern provinces of Guizhou 贵州 and Yunnan 云南 (see fig. 1), with the intention of modernizing their libraries, updating book collections, and promoting free access to information by providing computers and training in the use of the Internet to students and local residents. In 2002, the EEF set up an office in China-the China Evergreen Rural Library Service Center 中国青树乡村图书馆服务中心 (CERLS). As all foreign nonprofit organizations are required to register with the local government, the EEF coordinated activities through CERLS. For the next three years, the EEF funded the expansion of library book collections, the creation of large digital reading rooms with Internet connections, and the remodeling of the facilities of several school and county public libraries. The organization also wired satellite libraries dispersed

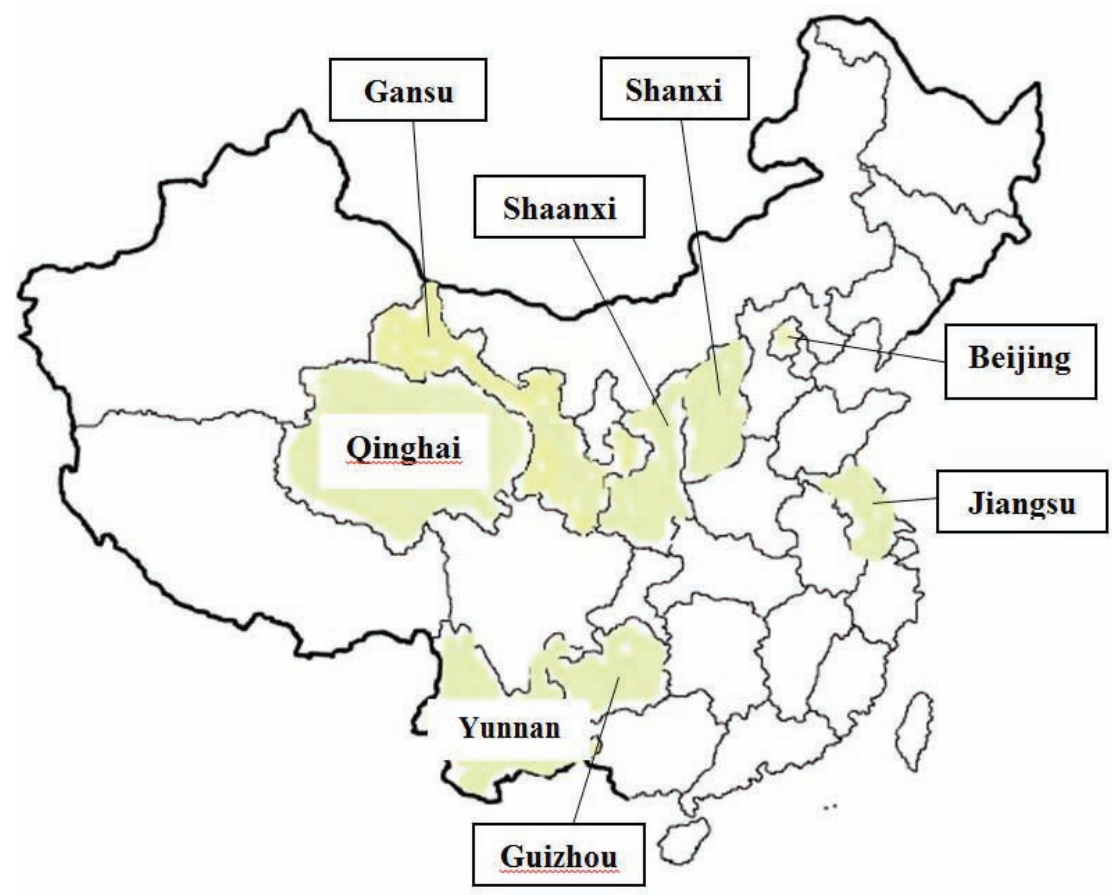

Figure 1. EEF-sponsored communities in China are located in Beijing and the seven provinces indicated on the map. 
throughout the Western rural areas. In short, the EEF's endeavors have helped connect people in many communities. They have slowly and steadily helped transform school libraries into community centers.

In 2004, CERLS received the prestigious Access to Learning award from the Bill \& Melinda Gates Foundation in recognition of its work. Since then, the EEF's library program has been significantly expanded. To date, CERLS has sponsored over forty-five libraries in Beijing and seven provinces of China, libraries whose services have reached about 84,000 students and a million-plus residents.

However, we want to point out that technology alone could not, and did not, bring about the necessary changes to communities. In many areas where CERLS chose to initiate library programs, Internet-enabled communication will never completely replace face-to-face communication, which is essential in rural communities. More work needs to be done before a true online community takes shape. In the two cases we present in this report, readers may recognize that at the current stage of the project, the majority of library users seem to be in a state of "online sometimes and off-line most of the time." However, readers should also recognize the seeds that the EEF has sowed. Through these two cases, the authors hope to shed light on how far the two high schools have progressed toward their goals.

\section{SCHOOL Library-CENTEREd COMMUNITy INFORMATION- Resource-Sharing Model}

The EEF rural library service concept evolved around a school librarycentered, community-based, information-resource-sharing model to connect geographically isolated communities through a network of libraries. This was part of EEF's plan to expand CERLS's circle of influence and to support school libraries in their efforts to train students in information and Internet literacy skills. The goals are dual: 1) to teach students to use library resources, especially computers, the Internet, and other technologies; and 2) to make it possible for the students to pass their knowledge on to their parents and others in their community; that is to say, create a chain of influence. CERLS also selectively included public libraries and mom-and-pop family book houses 书屋 in the villages in this chain of influence. Libraries in close geographic proximity to each other were wired as one library cluster that was open to all. Digital reading rooms in school libraries are available for classroom instruction and, when not scheduled for class use, to local residents for the purposes of searching the library's online catalog, using software on the PCs, and surfing the Internet. Typically, participating village book houses also have at least one computer with the same Internet connectivity (Zhou, Dong, \& Zou, 2008). 


\section{Connected Online and Offline}

All the CERLS computers come loaded with links to the EEF's website, which is maintained by EEF staff from the United States. The CERLS website, which serves as the online portal for CERLS library communities, is in Chinese and is managed by the high school libraries in China. CERLS libraries communicate with each other mainly through e-mail. Because popular social network software such as Facebook, Twitter, Google + and YouTube are not available in China, it follows that they are also not available in CERLS libraries.

Most families in rural communities cannot afford computers and Internet at home; in order to get online, they must visit their public libraries. Even members of the library staff are limited by economic means and technology access. CERLS libraries have conducted numerous workshops and tutoring sessions to train elderly residents and farmers to use computers and the Internet. This basic training includes instruction on finding the power button and launching a browser. In order to practice using these skills, most residents rely on the limited number of computers at the library nearby. But traveling to the libraries from the villages is not always easy, and the availability of computers is always a big problem. Students all have access to technology and the Internet through the school libraries' digital reading rooms. They are the direct beneficiaries of the EEF technology enhancement program.

CERLS libraries tend to include more online digital resources to supplement their book collection and database subscriptions. Many EEFsupported CERLS libraries also permit students to use computers and the Internet, especially to find relevant information on the Web. The libraries purposefully list and index the websites on school Webpp. for more users to read. However, the lack of computers in the remote areas has limited library users' access to the Internet.

\section{Connecting FACE-TO-FAGE}

Since 2003, the EEF has sponsored annual training workshops for staff and professionals in the CERLS libraries. In odd years a workshop on rural library development is held, and in even years an international conference takes place. These events facilitate face-to-face communication and interaction. They are times for CERLS libraries to establish and renew international connections. For each event, the EEF sponsors the participation of about 100 rural librarians and teachers, and invites an additional 100-300 delegates to the international conferences. The conference delegates and guest speakers come from around the world-the United States, Britain, Denmark, Greece, Taiwan, Hong Kong, Southeast Asia, and Mainland China-and consist mostly of professors, teachers, librarians, and NGO officials. 


\section{LeVeraging Support And Resources from the Community AND Society}

The EEF has effectively worked out a system that leverages social capital from local organizations, as well as knowledge and expertise from volunteers in the United States and China. When this project began, the EEF had only a small amount of seed money (about $\$ 120,000$ ). But in 2004, CERLS received $\$ 500,000$ from the Bill \& Melinda Gates Foundation Access to Learning Award. This award has enabled CERLS to allocate additional funding for its initiatives and programs. The bulk of EEF's financial resources consist of public donations in the forms of money, books, or supplies from the United States and China. In ten years, EEF libraries have benefitted from the labors of a large number of volunteers-students, teachers, staff from local schools, local residents, college students from big cities, as well as teachers and university professors from China and overseas. Many college students from metropolitan areas have traveled during their summer breaks to join EEF libraries' projects. Participating in these projects, they have learned firsthand about people living in underdeveloped communities, and have gained the experience of helping others with their education background and skills.

\section{Funding Methods and Projects Grants}

To ensure the sustainability of the CERLS programs and the diffusion of technology-enabled services, the EEF has continued to provide funds to support innovative projects through project grants. The organization encourages CERLS libraries' staff to submit grant proposals in which they link project outcomes to student learning and academic advancement, and to itemize budgets in terms of use of technology, travel, and supporting materials and resources. Proposals are all submitted electronically to CERLS, which forwards them to EEF's reviewers in the United States. The final selections are usually announced at the annual conference or at workshops in China. Other than face-to-face contact at the annual meetings, the Internet and e-mail have been the only means to move information through the international EEF network. These grassroots projects usually submit fairly small budget requests.

Over the years, the EEF has funded over seventy small, one-year projects and three large projects. Small-project grants are awarded in the amount of $\$ 800$. The large ones can be as much as $\$ 30,000$. An example of a small project is the Online with the Elderly Program 青树小项目 “携老上网游. This project一administered by the Tongwei County Public Library-aimed to help elderly residents in the local community learn how to search on the Internet and improve their information literacy. An example of a large project is the Farmers' Information Literacy Training Project in Tianzhu 天祝农民信息技术培训项目, which teaches groups of local farmers how to use computers and the Internet, with a special focus 
on search engines and agricultural portals. For this project, CERLS established an online information and discussion forum for discussion and knowledge sharing among trainers and trainees alike. The other large projects are the Oral History Program 天祝口述历史和民间文化实录项目 and the Health and Wellness Information Literacy Program 通渭健康教 育项目. These two projects are the subject of the rest of this report.

\section{Programs Sponsored by the EEF in the Two Counties}

\section{About the Two Counties}

Tianzhu 天祝 and Tongwei 通渭 are two counties in Gansu Province 甘肃省一which lies between the Tibetan Plateau 西藏高原 and the Loess Plateau 黄土高原. It borders Mongolia 蒙古 to the northwest, Inner Mongolia 内蒙古 and Ningxia 宁夏 to the north, Shaanxi Province 陕西省 to the east, Sichuan Province 四川省 to the south, and Xinjiang 新疆 to the West. As figure 2 indicates, Gansu Province includes the geographical center of China.

Tianzhu County, with 9 towns, 10 townships, and 176 villages, has a population of 230,000. Of this number, national minorities (representing 15 ethnicities) comprise 37.14 percent. The largest ethnic minority group

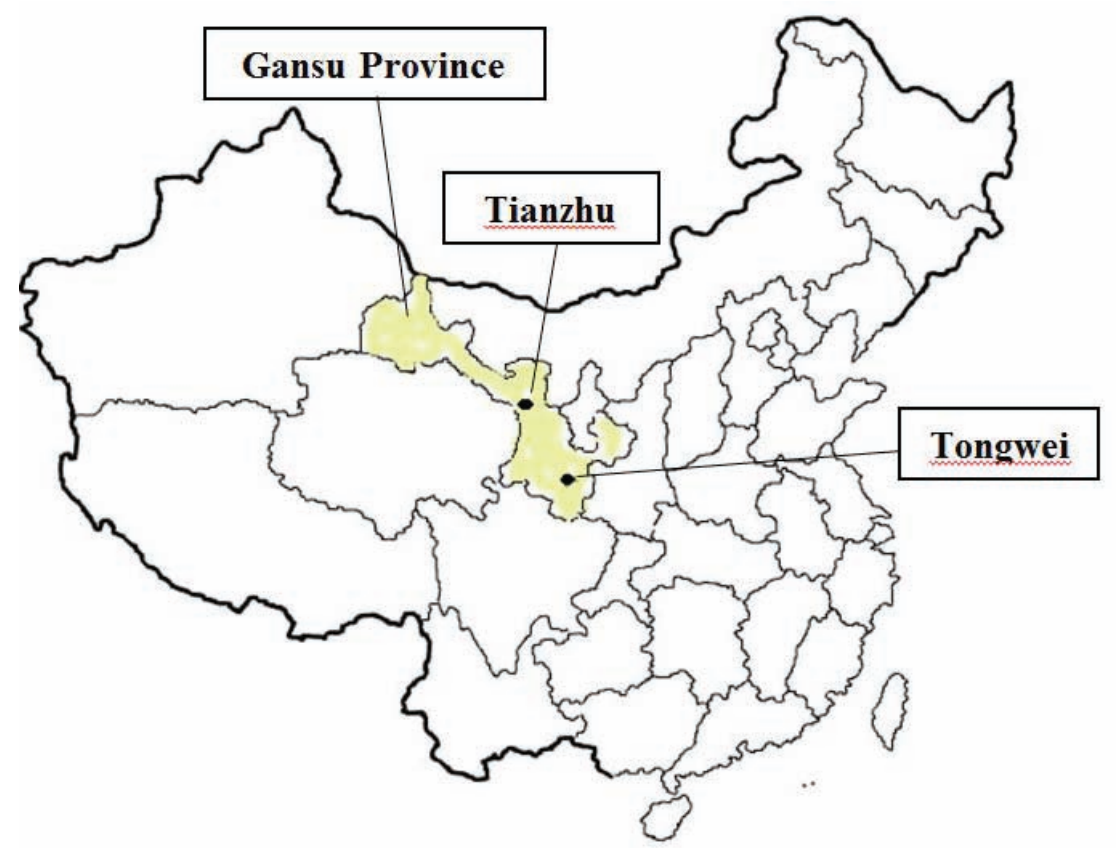

Figure 2. Maps of Tianzhu, Tongwei, and Gansu Province. 
is Tibetan, which makes up 36 percent of the county's population. Because of its ethnic diversity, Tianzhu was the first county to be designated as a minority autonomous county by the central government, in 1950. In 2011, the average annual income per rural resident was 3,199 RMB (Tianzhu County Bureau of Statistics, 2011). Situated along the ancient Silk Road, Tianzhu has a rich, distinctive, and colorful heritage-of art, music, folklore, ritual, costumes, cuisines, herbal medicine, and religionsthat is very much alive today.

Tongwei County lies to the south of Tianzhu, and has 18 towns and 332 villages. Its population is 446,700 and is exclusively Han Chinese. Ninety percent of the county's residents are engaged in agricultural occupations. The average annual income per rural resident was 2,883 RMB in 2011 (Tongwei County Bureau of Statistics, 2011). The terrain of Tongwei is mountainous with numerous gullies running through it. This region's history of floods, droughts, and soil erosion has slowed its economic progress. Both counties have been identified by the government as being among the poorest in the country and have thus qualified for receiving poverty-alleviation subsidies.

\section{The Digital Divide}

If we could rewind back to 2001 in Tianzhu and Tongwei, we would find that none of the public and school libraries there had computers, much less free Internet access for the general public. In that year, the digital and communication revolution had just begun to touch the northeast and southeast coastal cities of China. At the time, the total number of Internet users in China was only 22.5 million, barely 5 percent of the country's population (CNNIC, 2003). ${ }^{1}$ The digital and technological divides characteristic of rural regions were even deeper for children, elderly, and farmers. Eighty-eight percent of Internet users were people who had at least a high school degree. People aged fifty or older made up only 3.7 percent of the total Internet users. The rural agricultural population (which accounts for about 80 percent of the total population in China) made up only 1 percent of the total Internet users (Chen \& Wellman, 2009). It was with these statistics in mind that the EEF established its CERLS Center in Western China.

\section{Programs in the Two Counties}

In 2002, the EEF formed partnerships with a high school in Tianzhu and another in Tongwei to upgrade their library collections, technology, staff training, and facilities. The initial success of these partnerships solidified the direction that both the schools' administrators and the EEF would embrace: they decided to expand the existing partnership by building alliances with more local public and school libraries in an attempt to deliver services to more community residents. Project team members understood 
that efficient and effective library service can best be achieved through sharing resources, expertise, and facilities.

\section{Tianzhu No. 1 High School Library}

Although Tianzhu No. 1 High School's Library was considered the best school library in the county, its book collection was seriously inadequate and outdated. Additionally, before 2002, the library had no computers. The EEF donated 170,000 RMB to the school for the expansion of its collections and facilities, along with the purchase of computers and audiovisual equipment. Funding from the EEF also allowed the school to send librarians and teachers to workshops and conferences. Today, the library is equipped with an integrated library system and a digital lab with networked computers and printers. The book collections have been sufficiently updated and now total 87,000 volumes to support the teaching and curriculum. The library holds regular writing contests and guestspeaker events for students and undertakes outreach to neighborhoods and communities. In addition, it delivers services to farmers and herdsmen through a collaborative satellite network that includes a public library, three middle school libraries, two elementary school libraries, and one book station. Through this network, the library has offered training courses on how to search for information about agriculture and farming skills. It also started an oral history project to interview native populations and collect and preserve their stories and cultures.

\section{Tongwei High School Library}

Before 2002, public and school libraries in Tongwei faced crippling economic constraints. Their small and outdated book collections failed to meet the needs of local residents. In 2002, EEF began to provide funding to two key libraries in the county-the Tongwei County Public Library and the Tongwei No. 1 High School Library. EEF's funding was used specifically for funding new services and programs, acquiring software and hardware, and covering the expenses associated with the training and professional development of library staff. EEF's support has helped to bring about some impressive changes. Today, Tongwei County Public Library has a book collection of 50,000 volumes, and Tongwei No. 1 High School Library has 35,000 volumes. Both libraries have established healthy annual budgets for books and periodicals and acquired an integrated library management system. Each library has its own electronic reading room, featuring sixty networked computers that can be used to search the library catalog or access information on the Internet.

In addition, in an effort to serve their broader communities, the two libraries collaborated with two middle school libraries and two library service stations to form a resource-sharing cluster-the Tongwei Evergreen Rural Library 通渭青树乡村图书馆 (TERL). In this alliance, the two EEF-funded 
libraries serve as central libraries and the other libraries as satellites. All the libraries are connected through a shared ILS system and via the Internet. Local residents with a TERL card can use library services at any of the libraries in the cluster. What is unique to the TERL is that by enabling individual libraries to broaden their missions, it helped abolish traditional distinctions between public and school libraries. Both kinds of libraries have extended their service offerings and made joint efforts to reach out to local and rural residents and deliver programs that develop information literacy.

\section{The Projects: Identical Model with Different Focuses}

The Tianzhu Oral History Project (May 2009-present)

天祝口述历史和民间文化实录项目

The IFLA Multicultural Library Manifesto stresses that "Cultural and linguistic diversity is the common heritage of humankind and should be cherished and preserved for the benefit of all.... Libraries of all types should reflect, support and promote cultural and linguistic diversity at the international, national, and local levels" (IFLA, 2009). Tianzhu's rich and diverse cultural heritage and history has been passed on from generation to generation through individuals who were masters of certain forms of arts and languages. Although many of these individuals had no formal education, they mastered their specialties through years of study and performance. The danger of losing this cultural heritage looms large as people migrate or pass away and as ethnic languages and dialects are marginalized by the major written languages. As a result, the preservation and promotion of these endangered cultures has become a top funding priority. EEF wished to make it possible for young people to learn the histories of their communities and in the process, gain exposure to archival media and technology and learn research skills. For this particular project, the Tianzhu Evergreen Libraries' objectives were to: 1) identify and interview elderly storytellers, performers, and shamans; 2) process, index, and transcribe the interviews; 3) build a digital oral history collection; and 4) make the collection accessible on the Internet in multiple formats. For several reasons, the project was to be managed by the high school library: it had the best digital equipment and the best resources in the county; it had a large pool of students that could be trained to assist in conducting interviews and processing the recordings; and it had direct support and training from EEF experts in China and the United States on oral history archiving methods and techniques.

Tianzhu No. 1 High School Library initiated the Tianzhu Oral History Project in May 2009. With guidance from experts and support from the EEF and the school administration, project team members recorded interviews with digital cameras and audiovisual recorders. They also did 
postinterview processing work, created a digital archive, and displayed and promoted the collection through the media and on the Web. The project has had six phases and is ongoing.

\section{Phase I. Project Planning and Training (May-September 2009)}

Planning. In May 2009, Tianzhu No. 1 High School Library drafted the Project Implementation Plan. The plan addressed three project goals: 1) to preserve and promote local culture; 2) to cultivate students' curiosity about local history, research methodologies, communication skills, multimedia computer skills, and teamwork; and 3) to improve the relationship between the school and the local community. Along with these goals, the plan identified three major interview themes: folk art and culture, social life, and campus life. The plan also defined assessment methods and identified the Internet and local radio and television stations as channels for promotion and marketing.

Assembling the Project Team. The library received substantial support from school administrators, teachers, students, and the local community for the project. The school held a mobilization meeting to recruit volunteers and get community support. The school principal, Mr. Guodong Jiang, led the project. Several literature and history teachers as well as students volunteered to join the team. A computer teacher was recruited to manage the related digital files. A number of experts in the areas of oral history and folk art and culture were invited to join the consulting group. Librarians were responsible for collecting, organizing, and archiving related documents and recordings and coordinating the project and training.

Collecting Information and Selecting Interviewees and Topics. In order to get the "right" interviewees, school librarians did thorough research using online and library resources such as local news reports, directories, biographies, and archives. They also openly invited recommendations for interview candidates and specific topics. After making a list of people for interviews, team members conducted further research to learn everything they could about the people they planned to interview, which helped them develop specific questions and tailor the interviews.

Training. Experts were invited to teach project members the necessary skills in four areas: local documents and folk art and culture; interview procedures and techniques; audiovisual recording equipment; and processing and editing software. Since oral history is a new area of study in China, there is limited information and resources in Chinese on the subject. School librarians and experts did research and compiled several training brochures based on references in English. Professor Liyun $\mathrm{Hu}$ 胡立耘 from Yunnan University gave a series of training workshops on the history and techniques of oral history programs. School librarians, with the help of experts, also drafted a project procedure manual for project 
team members. The content included a project schedule, progress report, an interview checklist, a step-by-step guide, an interview outline, contracts, and archiving procedures.

Phase II. Preliminary Interviews and Archiving (October 2009-June 2010). In October 2009, fifteen students and five teachers completed preliminary interviewing and recording tasks using digital cameras and tape recorders. By June 2010, the team had completed seven interviews following the project manual. The interviewees include a Tu AnZhao rap musician 天 祝土族安召说唱艺人, two Tu culture scholars 土族文化学者, a Tibetan culture scholar 藏文化学者, a Tibetan Thang-ga painter 华锐藏族唐卡画 师, a folk painter民间画师, and the chair of the Tianzhu County Writers Association 天祝县作协主席. Team members then edited and processed these audio and video recordings using special software. They also added full or partial transcripts based on the recordings and interview logs in order to help viewers better understand the interviewees (who spoke in various dialects). All the textual and audiovisual documents were indexed and described in abstracts and were then archived with the school library.

Phase III. Assessment and Digitization (July-December 2010). In July 2010, team members did a preliminary assessment to understand the issues that most often came up in the interviews and decided to focus mainly on the theme of folk art and culture for future interviews. Between July and September 2010, the team members interviewed a performer of Tibetan wine songs 藏族酒曲 and several Shehuo 社火曲子(traditional festive affairs) performers. From October to December 2010, the team recorded Tibetan and $\mathrm{Tu}$ weddings. Team members then edited and digitized the completed video recordings and produced six digital videos: Tu Culture 土族文化的变迁, Tu Anzhao Rap Music 土族安召, Tianzhu Yak Culture 天祝牦牛文化, Tibetan Wine Songs 藏族酒曲, Tibetan Culture 藏族文化 的变迁, and Thang-ga Painting 唐卡制作.

Phase IV. Investigation of Digital Collection Systems and Metadata Schemes (January 2011-present). All oral history projects face the question of how to store audiovisual files, transcripts, and other materials safely and securely for long-term preservation and access. In order to store and backup large audiovisual files, hardware must be managed and maintained. Describing the provenance of digital files and providing access points requires strong metadata design, creation, and maintenance. And the tasks of organizing, preserving, and offering access to digital files requires an appropriate digital content management system.

The team planned to build a digital collection management system that would offer an easy way to collect, store, preserve, and retrieve these interviews and related information. Members of the team agreed that the access points for search would include subject, keyword, interviewee name, document type, and other metadata fields. So far, the team members have gotten as far as investigating digital collection management software such 
as Kete and Greensone, and studying oral history websites of a wide range of national libraries, college libraries, folk culture research institutes, historical associations, and other institutions-including In the First Person, an oral history database created by Alexander Street Press.

Team members also learned that the metadata schemes for these oral history collections and systems are most often Dublin Core based. After study and discussion, team members agreed that the Dublin Core scheme would work for the project. Together, they identified fifteen metadata fields adjusted according to the Dublin Core set-including title, creator, contributors, date, source, description, coverage, type, format, language, subject, relation, rights holder, and identifier for resource URL. The interview log was designed to include all these fields so that metadata could be collected from the beginning (Hu \& Jiang, 2010).

Phase V. Publicity and Resource Sharing (January 2011-present). The digital collection management system for the project is still under construction, so team members have created a temporary website to share some information on the project (Tianzhu Oral History Project, http://210.51.57.80/ oralhistory/). They have uploaded recordings of interviews to both the website and to Youku.com 优酷网 (the Chinese "You Tube"). The project team has publicized the project via local museums, festivals, exhibitions, media, and the Evergreen conference and website. Some of the project's interviews have also been broadcast on local radio and television.

Tianzhu No. 1 High School Library set up a local culture room to showcase the finished products alongside related documents, books, periodicals, magazines, letters, paintings, photos, crafts, and artifacts pertaining to local culture and history. These materials are available to all. The school also developed an interdisciplinary (history/literature) curriculum, "Oral History and Folk Culture," and compiled a textbook on this subject. The audiovisual materials collected and produced in the project were used in the class as well as in other literature and history classes. Teachers and students were encouraged to write research reports and create literary works using these primary materials.

Phase VI. Project Extension (January 2011-July 2012). At the beginning of 2011, team members reviewed the project's progress, and drafted a Project Implementation Extension Plan, which revised initial project objectives. Following this plan, team members extended the depth and breadth of the project in the following areas:

- They recruited more volunteers, and offered team members more training in interview skills and audiovisual recording and processing techniques.

- They expanded the scope and topics of the interviews. In March 2011, team members interviewed some school students on several subjects: favorite colleges and universities 高考心态, idols 偶像崇拜, fashion and 
style 我的时尚观, ideas of happiness 我的幸福观, and favorite books 阅读体验. These videos helped teachers better understand their students in order to improve the quality of education.

- They helped the school create an Oral History Club. By March 2012, 130 students had joined the club. The club organized various activities, including inviting an expert in June 2012 to give a talk on oral history.

- They investigated and selected more topics for interviews. During this period, the team members did interviews about Tianzhu folk music 天祝民间音乐文化, Tibetan costume making 华锐地区藏族服饰的加 工和制作, Tibetan wines and winemaking 藏酒的酿造和加工技术, and horse racing in Tianzhu 天祝赛马. They also completed the interview series on Tibetan wine songs 藏族民间酒曲.

Taking into consideration the high rate of illiteracy and scattered way of life of local pastoralists, Tianzhu No. 1 High School Library organized discussion forums as a method to gather feedback and understand the effect of the project. Discussion with over one hundred pastoralists found that satisfaction rates for the project hover at about 86 percent. Some interviewees did not know the project before the interviews, but once introduced to it, they showed great interest. Eighty-seven percent of the interviewees requested copies of the project videos. Some suggested that project videos be broadcast more than once on local television and uploaded to more websites so that more local residents could view them. They also hoped that the quality of production and marketing strategy would be enhanced.

The Oral History Project preserved and promoted indigenous and intangible cultural heritage, attracted users from different ethnic and cultural backgrounds, and served diverse interests and communities. The project has also been an educational watershed. It has helped students learn to use a diversity of information technologies and research skills, to work with a team, and to communicate more effectively. In return, the project will get sustainable support and volunteers for future projects.

\section{Tongwei Health and Wellness Education Project 通渭健康教育项目} (July 2009-July 2012)

In an effort to understand the information needs of rural residents, the TERL 通渭青树乡村图书馆 randomly surveyed 200 rural residents in four communities-Tongwei township 通渭县城城区, Zhonglin Village of Pingxiang Township 平襄镇中林村, Pingchuan Village of Maying Township 马营镇平川村, and Puwan Village of Disanpu Township 第三铺乡蒲 湾村. The results presented in tables 1 and 2 are based on 196 qualified returned surveys.

As table 2 demonstrates, survey results confirmed that respondents who were older than twenty years of age ( 80 percent of the total respondents) were mostly interested in information pertaining to health and medical care. The degree of interest was positively correlated to age pro- 
Table 1. Demographics of the 196 Tongwei Residents Who Responded to Our Survey

\begin{tabular}{|c|c|c|c|c|c|c|c|c|c|c|}
\hline & & & & & & \multicolumn{5}{|c|}{ Education Level } \\
\hline \multicolumn{2}{|c|}{ Sex } & \multicolumn{4}{|c|}{ Age, $y$} & \multirow{2}{*}{$\begin{array}{c}\text { Elementary } \\
\text { School } \\
\text { and } \\
\text { Below }\end{array}$} & \multirow{2}{*}{$\begin{array}{l}\text { Middle } \\
\text { School }\end{array}$} & \multirow{2}{*}{$\begin{array}{c}\text { High } \\
\text { School/ } \\
\text { Vocational } \\
\text { School }\end{array}$} & \multirow{2}{*}{$\begin{array}{l}\text { Com- } \\
\text { munity } \\
\text { College }\end{array}$} & \multirow{2}{*}{$\begin{array}{l}\text { Four- } \\
\text { Year } \\
\text { College and } \\
\text { Beyond }\end{array}$} \\
\hline M & F & $\leq 20$ & $21-40$ & $41-60$ & $>60$ & & & & & \\
\hline 110 & 86 & 38 & 63 & 56 & 41 & 29 & 48 & 67 & 28 & 24 \\
\hline $56 \%$ & $44 \%$ & $19.3 \%$ & $32.1 \%$ & $28.6 \%$ & $20 \%$ & $14.7 \%$ & $24.6 \%$ & $34.2 \%$ & $14.3 \%$ & $12.2 \%$ \\
\hline
\end{tabular}

Table 2. Information Needs of Tongwei's Rural Residents, Based on Survey (N = 196)

\begin{tabular}{lccccccc}
\hline Age, $y$ & Housing & Employment & $\begin{array}{c}\text { Health and } \\
\text { Medical Care }\end{array}$ & Education & Law & Economy & Agriculture \\
\hline$\leq 20$ & 10 & 11 & 5 & 9 & 1 & 1 & 1 \\
$21-40$ & 13 & 7 & 17 & 11 & 2 & 3 & 10 \\
$41-60$ & 9 & 10 & 18 & 4 & 4 & 3 & 8 \\
$>60$ & 6 & 5 & 19 & 3 & 2 & 1 & 3 \\
Percentage & $19.3 \%$ & $16.8 \%$ & $30 \%$ & $13.8 \%$ & $4.5 \%$ & $4 \%$ & $11.2 \%$ \\
\hline
\end{tabular}

gression of respondents. Older respondents were more concerned with their health and were interested in health care literacy. Across all the age groups, the respondents were also more interested in health and wellness information than in the other six types of information. A follow-up survey was subsequently sent to the same population to further understand their level of health literacy and lifestyles affecting their health.

As table 3 suggests, local residents paid little attention to their health due to the lack of health and wellness information and education. As many as 76 percent of them acknowledged that they had never read about or searched for health care information; 64 percent said they did not exercise or play sports; 68 percent were smokers; 81 percent had never had a regular health checkup; and 51 percent suffered from sleep deprivation. As this is a region largely relying on agriculture, long hours of toil dominate the daily life of the farmers, and sleep deprivation is a major health problem. In January 2009, the TERL rolled out a health information literacy program aimed at helping the local residents alter their life-

Table 3. Health Issues and Awareness of Tongwei's Rural Residents, From Follow-up Survey

\begin{tabular}{|c|c|c|c|c|c|}
\hline & $\begin{array}{c}\text { Never } \\
\text { Exercise }\end{array}$ & Smoking & $\begin{array}{c}\text { Never Had } \\
\text { Health } \\
\text { Checkup }\end{array}$ & $\begin{array}{c}\text { Sleep } \\
\text { Deprivation }\end{array}$ & $\begin{array}{c}\text { Never } \\
\text { Read or } \\
\text { Researched } \\
\text { Health } \\
\text { Information }\end{array}$ \\
\hline No. of Respondents & 125 & 133 & 158 & 99 & 148 \\
\hline Percentage & $64 \%$ & $68 \%$ & $81 \%$ & $51 \%$ & $76 \%$ \\
\hline
\end{tabular}


styles and habits. The program was funded for three years and had two integral objectives: to promote health care literacy and to convince local residents to have regular medical checkups. The implementation of the program involved five phases:

Phase I. Prepare and customize health care information in accordance with the needs of identified demographic groups. A preliminary study suggested that age and economic status were two key factors affecting rural residents' needs for health information. The TERL wanted to identify the health information most relevant for different demographic groups and select and deliver resources to them accordingly.

The TERL adopted several methods to obtain information from users. For the younger population, the TERL started with school students at Tongwei No. 1 High School. With the support of the school administration, a standard for health and wellness and an annual checkup were instituted to track students' health status. In studying 4,992 students' annual checkup reports over a three-year period, the three most common health problems were identified: decreased vision (56.06 percent), dental issues (3.79 percent), and tonsillitis (2.23 percent). The TERL prioritized their education objectives to emphasize visual health literacy and relevant information for the other two topics. For other population groups, such as women and senior residents, TERL staff, using surveys and personal interviews, sought feedback from those who visited the libraries. For those who lived in rural areas and did not visit the libraries, TERL staff scheduled field trips to those areas to obtain their feedback. The data gathered through the process is presented in figure 3 for program-design and information-procurement purposes.

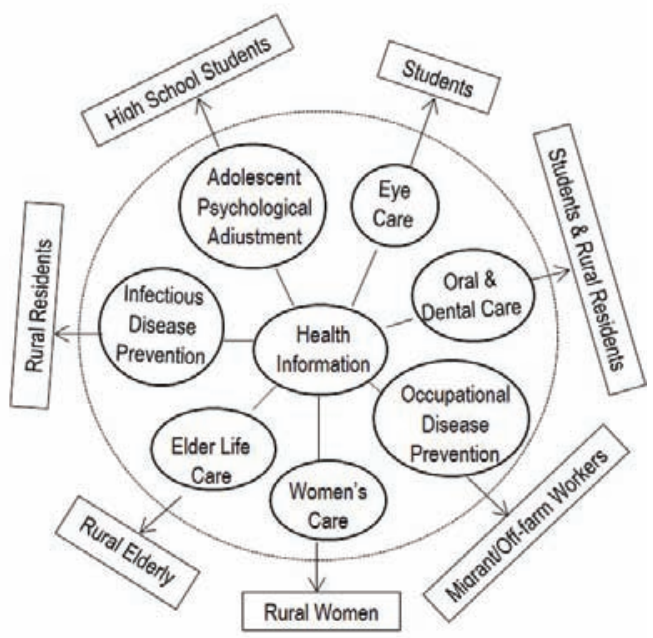

Figure 3. Health information needs of Tongwei's rural residents. 
Phase II. Develop a health information and education network and a resourcesharing alliance. The county public library and the high school library were the catalysts of the program. Each library targeted their primary users. The high school library decided upon five initiatives, as shown in figure 4. They compiled a Handbook of Health Education 健康教育手册. The handbook discusses common health issues and prevention strategies for teens. It also includes information on eye, ear, nose, and throat health and on common diseases such as food poisoning and diseases transmitted by animals in farming and agricultural areas. The school adopted the handbook as the required textbook for its health education classes. In keeping with the main theme of health for teens, the TERL hosted seminars on puberty and female health and sponsored writing contests and poster competitions on various health themes. TERL staff also visited communities to promote oral-disease prevention information with presentations and seminars.

At the same time, the county's public library decided upon six initiatives, as shown in figure 5 . They started publishing a bimonthly publication, Health and Wellness Digest 健康文摘. The theme for each issue alternates according to the season and features topics addressed at a rotating roster of demographic groupings. For example, the issue that came out around the Chinese New Year was devoted to migrant workers returning home for a holiday break, and the articles selected were about occupational disease and prevention. An issue for rural residents had articles pertaining to the biology of aging and the pathophysiology of age-related diseases. A special issue for children featured articles on oral health information. Since its inception, sixteen issues have been published. The county public library also allocated funds for developing a collection of health and wellness materials and setting up display shelves for books and periodicals pertaining to the health topics. The public library is also responsible for hosting monthly health education seminars and discussion groups, organizing competitions for health-related essays and paintings,

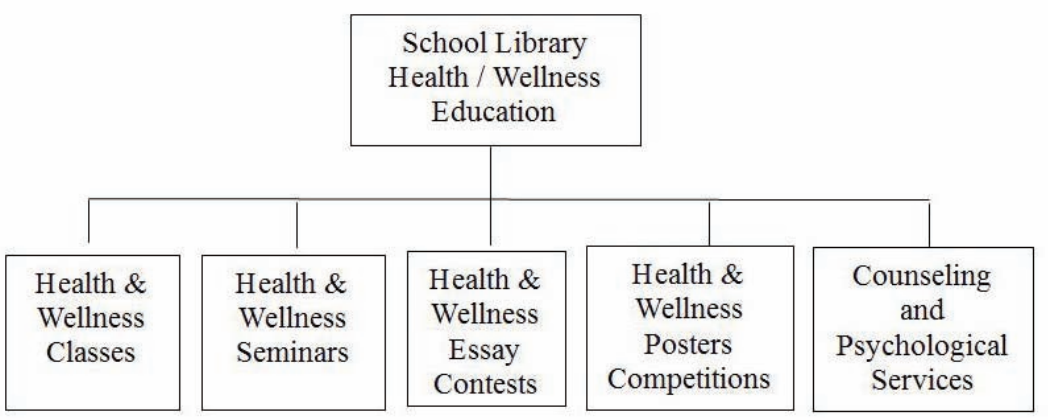

Figure 4. Health and wellness education initiatives by Tongwei No. 1 High School Library. 


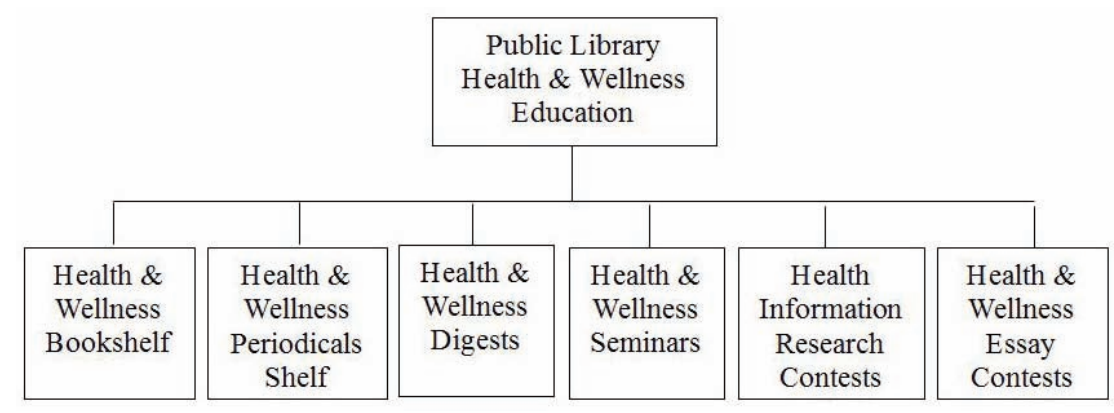

Figure 5. Health and wellness initiatives by Tongwei Public Library.

and awarding users for recommending the most informative websites. So far, they have coordinated sixteen open forums of this kind.

Phase III. Replicate these activities at the satellite libraries and expand the program. After the implementation of Phase II, the TERL did an assessment, before moving forward to replicate the services at satellite libraries, particularly of the programs deemed popular and desirable (e.g., Health Education Classes for Teens). They also further tailored the programs (e.g., Health and Wellness Seminars) based on attendants' suggestions and comments. Three strategies have been outlined for further development:

- Enrich the content and encourage user involvement. Continuous refinement and expansion of these well-received programs helped broaden the base of regular participants, who in turn brought additional participants with them. The TERL valued and encouraged users' participation and interactive learning experiences. They enlisted students in organizing and leading book reading clubs and health film showings, so that they became promoters of these programs.

- Be more creative with outreach methods. As new ideas and suggestions were brought forth, the TERL promptly but selectively adopted them. To strengthen and expand the established programs, the TERL began to offer counseling services at the high school library and held fifty-six mental health literacy sessions with groups of students. TERL teachers also offered individual counseling to more than twenty seniors who had experienced anxiety and stress in preparing for their college entrance examinations. This was in addition to the group counseling for all senior students before their college entrance examinations. The public library has since expanded its health education film series. A cartoon film, Adventures in the Tooth Kingdom 牙齿王国历险记, was shown 6 times to a total of 572 children.

- Branch out and deliver programs to the communities. In order to reach out to local residents, the TERL mobilized all the affiliated libraries 
and services within its resource-sharing alliance. They delivered the Health and Wellness Digests to farmers in the fields and engaged them in conversations on health literacy topics in their homes. They invited oral-health-care professionals to their seminar sessions at the satellite libraries to teach oral-health literacy classes and demonstrate the correct way to brush and floss teeth. Through various channels and locations, they continued to expand the delivery sphere so that more residents in remote and smaller communities could receive their publications.

Phase IV. Build shared resources and collections and maximize the TERL's effectiveness and impact. The TERL is committed to offering free health information literacy services and making the information available at all of their affiliated libraries and service locations. TERL cardholders can borrow books and periodicals from any of the TERL service locations. Print issues of the Health and Wellness Digests are delivered to all non-TERLaffiliated schools and libraries free of charge. The TERL has utilized social media to reach out to bloggers and has digitized their publications for Web posting so that people can find and read them anywhere, anytime. Their outreach follows the model presented in figure 6.

Phase V. Promote and deliver health information through information technology instruction. While the TERL has made much of the fact that its health literacy information is available on the Web via blogs for easy access anytime anywhere, its members also realized that only a limited number of people accessed these Web resources. TERL learned from surveys that many local residents did not know how to use a computer to surf the Internet. (The technology divide has become a big obstacle to overcome.)

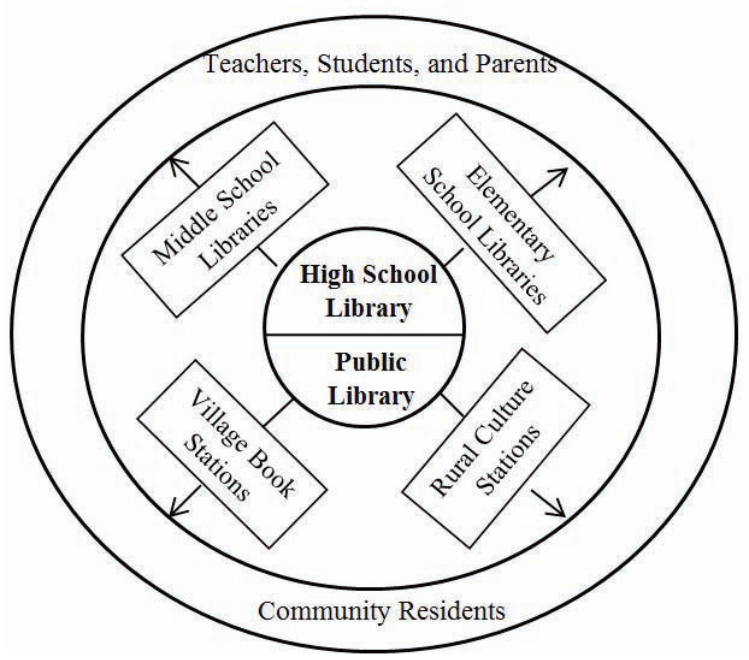

Figure 6. Health-information resource sharing model in Tongwei. 
As a follow-up the TERL developed yet another initiative-Internet literacy training (equivalent to "Internet for Dummies"), targeting library visitors who were willing to stay for a "crash course on using the Internet." The public library purchased thirty electronic character-recognition boards for library users who did not know how to type on a keyboard or had no training with phonetic symbols. The training started with very basic instructions such as where the power switch is and how to log into the network with a user name and password. After much practice, trained users can comfortably search and navigate the Web. Their search skills enable them not only to access the TERL Web resources but also use popular search engines and popular sites to search for other information. This Internet literacy training has opened up a new world for them. By word of mouth, more users have been drawn to the library for these training sessions for the reasons that either they do not have a computer or the Internet at home or they had thought the Internet was beyond their level of understanding.

An assessment of the program was conducted at the end of 2011 and the beginning of 2012. The TERL randomly surveyed over three hundred rural residents in two villages where oral health education was provided. The result shows that the residents' awareness of oral disease and prevention had increased from 32.1 percent to 72.3 percent. The survey of the readers of the Health and Wellness Digest found that migrant workers' awareness of occupational diseases and prevention increased from 21.3 percent to 62.1 percent, one year after its inception. The satisfaction rate for all the health education programs reached 81 percent. The survey also showed that rural residents would like the TERL to continue to carry out these programs. They also wish that medical professionals would come to their houses to do physical checkups and provide health consultations. The survey of Tongwei No. 1 High School found that students who received physical examinations, health education, and counseling had much better health conditions than other students. See table 4 for details.

Table 4. Students' Health Condition in Tongwei No. 1 High School

\begin{tabular}{lcc}
\hline & $\begin{array}{c}\text { Students Participated } \\
\text { in Health and } \\
\text { Wellness Program } \\
\text { and Had Physical } \\
\text { Examination }\end{array}$ & $\begin{array}{c}\text { Students Neither } \\
\text { Participated in Health } \\
\text { and Wellness Program } \\
\text { nor Had Physical } \\
\text { Examination }\end{array}$ \\
\hline Mental health problems & $1.9 \%$ & $2.5 \%$ \\
Enlarged tonsil & $2.23 \%$ & $3.23 \%$ \\
Dental caries & $0.43 \%$ & $0.79 \%$ \\
High blood pressure & $0.36 \%$ & $0.47 \%$ \\
Heart disease & $0.01 \%$ & $0.03 \%$ \\
\hline
\end{tabular}




\section{Analysis: The EEF Model of Library Cooperation}

The two cases of Tianzhu and Tongwei in this study offer an example of the collaborative service model that has been adopted by EEF-sponsored libraries in rural regions where public education and information services are still lagging due to economic constraints. The EEF service model has been able to fill in the gaps and achieve positive results. Because the EEF is a nongovernmental organization and has no administrative authority over the libraries it sponsors, it has only played an advisory and facilitating role in the partnership. Both the EEF and EEF libraries insisted on developing this unique model of funding and management that is flexible with a simple application process, in contrast to the government funding structure that is rigid and restrictive.

With local and rural libraries, the EEF found its niche in working with the government school systems. More importantly, the EEF model has proven to be executable. Rapid and steady economic growth has allowed the central and local governments to allocate more funding to improve cultural and education services. Large national projects, such as the $\mathrm{Na}-$ tional Cultural Information Resources Sharing Project 全国文化信息资源 共享工程, are funded and directed by the central government and under the supervision of provincial bureaus of cultural affairs. But these topdown grandiose projects can hardly reach the small and remote communities. $^{2}$

The EEF's model, on the other hand, starts from the grassroots and bubbles up. It works across the boundary that has traditionally separated educational functions from cultural functions of government-funded public institutions and services. Typically, a local cultural center is managed by the Department of Cultural Affairs and a school is supervised by the Department of Education. Funding from each of these government entities cannot be combined and is, therefore, not transferrable for other purposes. Government funding for promoting culture and the arts is rarely distributed to a public school, and educational funding is not to be used for cultural promotion programs. The EEF's model connects schools with public libraries and education activities with cultural programs. Its funding is more flexible since it is not subject to government restrictions.

A high school-based information center has other benefits. The existence and sustainability of small community libraries depends on modest start-up funding, and sustainability has been a major challenge. This requires continued funding but may not yield tangible returns in the short term. Affiliation with EEF high school libraries allows these libraries to benefit from a resource-sharing alliance and become part of larger outreach programs. The satellite libraries, on the other hand, help EEF libraries deliver services to the end users.

The EEF offers flexible funding policy and application procedures. Educational and cultural programs, along with projects relevant to the needs 
of communities, are most likely to receive funding. The Tianzhu Oral History Project is just one example. Additionally, the EEF helps libraries with necessary training, professional consultations, and assessment through its pool of volunteers from the United States. The EEF does not oversee or control affiliate libraries' decisions on policies and budgets. It works with the schools that receive their support and provides professional advice. Last, the EEF makes a long-term commitment in terms of supplying equipment and technology, as well as training and professional development for librarians and staff, which builds mutual trust. This model of partnership can be emulated by other NGO organizations working in China.

EEF libraries are fully aware of the "digital divide" in the communities they serve. Information illiteracy among the rural residents has increasingly become a pressing issue that continues to hamper the libraries' efforts to promote digital information literacy. The work that EEF libraries have initiated is important and valuable for their communities. Nevertheless, EEF libraries services only cover limited areas. The concepts of building a collaborative service delivery network and connecting high school information service centers with satellite libraries and community book stations have challenged traditional definitions of community libraries in Western China.

EEF libraries have made a direct connection with high school students-and through them, families and communities. Tianzhu and Tongwei high schools have more than a thousand students enrolled between them. These students become the EEF libraries' core customers. Through them the libraries effectively connect to their parents and families. For parents, there is no better way to support their children's education than to support their library programs. Attending the libraries' programs, many parents feel that they are back in school and learning together with their children.

\section{Conclusion}

The partnerships between EEF and the growing number of EEF-supported libraries, particularly the two high school libraries we have chosen to analyze in this report, illustrate the interplay of a dual process of globalization and localization in social and cultural change in remote Western China. Readers may feel that the EEF is practically a Chinese local organization, given its ability to exert a significant social impact in delivering services for these communities.

There is a Chinese saying, "A single spark can start a prairie fire" 星星 之火可以燎原. The first spark that ignited the EEF library service movement was a purely conceptual initiative conceived in California ten years ago. This resulted in an impetuous visit by two EEF officials to the two poverty-stricken counties mentioned in this report. Nobody was certain 
then what would come out of the first partnership agreements with these rural schools. And no one expected that occasional, transoceanic connection would ignite the rapid spread of the EEF library resource-sharing concept, a long-tested U.S. idea, to leverage collective resources, facilitate cooperative services, and reduce operation costs.

Initially the EEF had to largely rely on librarians from the United States to educate Chinese librarians on how to set up library services, establish policies, manage user-centered programs, and utilize limited technological resources. For participating Chinese librarians and school administrators, the EEF opened a door for them to meet library professionals in the United States and other countries. They eagerly embraced opportunities to learn from their Western counterparts at EEF international conferences. Services and programs were largely under EEF advisement regarding the establishment of standards and policies that are considered the essences of public libraries in the United States and other developed countries. Library management concepts and practices were translated and selectively adopted by the EEF libraries. The EEF aided all schools with a similar funding formula and structure (provision of books, digital reading rooms, and computing equipment, and expansion of library facilities) and laid out similar expectations regarding outcomes.

The last five years, however, have seen an accelerated process of localization. A group of highly motivated and capable local leaders and volunteers has emerged to carry on the EEF's vision and mission. Chinese librarians' have gained control of these projects, making them innovative and creative campaigns that promote public service and community development. Backed by EEF funds, these librarians have made strides and exerted significant influence in their regions. At the same time, the information technology revolution has quickly reached the remote areas. This has helped EEF libraries reach out to the geographically scattered locations through new technologies and technology instruction. The school library-centered community information service cluster that EEF champions has spread to libraries in other rural regions. In the cases we presented, Chinese librarians have been successful with program planning and implementation. They have only just begun to pay more attention to program outcome assessment — which is understandable given their limited training and experience. Most importantly, the programs are more engrained in the local cultural and sociopolitical environment and are fully driven by the local communities' needs. Although the outcomes of the EEF library service campaigns were conceived in the United States, they were designed for and made in China. The EEF library program is a rare case in which a U.S.-based NGO ignited a grassroots campaign in China that subsequently grew into a successful and sustainable locally driven project. 
Appendix A. Information Needs Survey of Tongwei Residents

1. Your sex: A. Male B. Female

$\begin{array}{llll}\text { 2. Your age: } & \text { A. } \leq 20 & \text { B. } 21-40\end{array}$

$\begin{array}{ll}\text { C. } 41-60 & \text { D. }>60\end{array}$

3. Your education level:
A. Elementary school \& below
B. Middle school
C. High school/vocational school
D. Community college
E. Four year college \& beyond

4. How easy can you find the information you need?
A. very easy
B. easy
C. so-so
D. not easy

5. Can you find the information you need in time? A. yes B. no

Please check all that apply for the following questions:

6. What types of information do you need most?
A. Housing B. Employment C. Health care D. Education
E. Law F. Economy G. Agriculture H. Other

7. Where do you get information?
A. TV B. Radio C. Friends

E. School F. Internet

8. What factors impact your information access?
A. Money
B. Education level
C. Information awareness
D. Information literacy

\section{Appendix B. Health Style and Awareness Survey of Tongwei Residents}

1. Your age:
A. $\leq 20$
B. $21-40$
C. $41-60$
D. $>61$

2. Are you satisfied with your current health condition?
A. Very much
B. Yes
C. so-so D. No

3. What types of health information do you need most?
A. Cardiovascular information B. Lung
D. Healthcare E. Occupational disease
C. Hypertension
G. Cervical, lumbar, and hyperostosis H. Other

4. How often do you exercise every week?

$\begin{array}{llll}\text { A. never exercise } & \text { B. } \leq 2 \text { times } & \text { C. } 2-4 \text { times } & \text { D. daily }\end{array}$

5. How many cigarettes do you smoke a day?
A. none
B. $1-5$
C. $5-10$
D. $>10$

6. How many hours do you sleep a day?
A. $\leq 6$ hours
B. $6-8$ hours
C. 9-10 hours
D. $\geq 10$ hours

7. How often do you have physical examinations?
A. I have physical examinations annually and special examinations as needed
B. Only annual physical examination
C. Once every 2 or 3 years
D. Never had physical examination

8. Do you read or search health information from newsreports, magazines, and other resources?

A. Yes B. No 
Appendix A, in Chinese

附录A: 通渭县农村社区居民信息需求获取情况问卷

单选问题:

1. 您的性别是 ()

A. 男 B. 女

2. 您的年龄是 ()
A. 20岁以下 B. 21-40岁
C. 41-60岁
D. 60 岁以上

3. 您的文化程度是 ()
A 、小学及以下
B. 初中
C. 高中/中专
D. 大专
E. 本科以上

4. 您获取信息的方便程度是 ()
A. 非常方便 B. 方便 C. 一般 D. 不方便

5. 您能及时获得自己所需要的信息吗? ()
A. 能
B. 不能

可多选问题:

6. 您最急需的信息是 ( )
A. 住房 B. 就业 C.
D. 教育 E. 法律 F. 经济
G. 农业科技 H. 其他

7. 您获取信息的途径是 ( )
A. 电视
B. 广播收音机
C. 亲朋好友

8. 您认为影响您获取信息的因素是什么? ( )
A. 资金
B. 文化水平
C. 信息意识
D. 信息技能

Appendix B, in Chinese

附录B: 通渭县居民健康行为和意识调查

1. 您的年龄是 ()
A. 20 岁以下
B. 21-40岁
C. $41-60$ 岁
D. 61 岁以上

2. 您对目前身体的健康状况满意吗 ( )
A. 非常满意 B. 满意
C. 一般
D. 不太满意
E. 很不满意。

3. 目前您最需要的健康信息是: ( )
A. 心血管
B. 肺部呼吸
C. 高血压
D. 生活保健 E. 职业病

F. 五官 G. 颈椎、腰椎、骨质增生等 H. 其他

5. 您每周的锻炼频率是:
A. 从未锻炼
B. $\leq 2$ 次
C. 2-4次
D. 基本每天一次

6. 您每日吸烟的支数:
A. 0 支
B. 1-5支
C. 5-10支
D. 10支以上

7. 您每天睡眠时间:
A. $\leq 6$ 小时
B. 6-8 小时
C. 9-10小时
D. $\geq 10$ 小时以上

8. 您通常多长时间进行一次体检。
A. 每年体检一次, 并根据自己的情况做特别检查。
B. 每年单位安排体检一次, 您都是在最后期限勿勿完成。
C. 2-3年进行一次体检。
D. 我身体状况很好, 从不体检。

9. 您平时会阅读报刊杂志上的健康类新闻和文章吗:
A. 非常关注
B. 经常跳过, 转而关注其他

\section{Notes}

1. A 2003 CNNIC report of the digital divide charted the increase of the total number of Internet users in China from 620,000 in 1997, to 22.5 million in 2001, and to around 60 million in 2003 , in its total population of 1.3 billion.

2. Two major national projects, for example, funded by the central government and administered by the Ministry of Education are the China Education and Research Network 中 


\section{LIBRARY TRENDS/SUMMER 2013}

国教育和计算机网 (CERNET) and the China Academic Library and Information System 中国高等教育文献保障系统 (CALIS). CERNET was started in 1994 by a group of top national universities and became the first national Internet backbone It has become the largest state-owned academic and research network in the country. CALIS is part of the 211 national strategic plan that in 1990 established a mandate, and which in the subsequent 10 to 15 years envisioned the building of one hundred tier-one comprehensive research universities. CALIS was arguably the most ambitious plan of the 1990s in terms of building a national digital library and information support systems that utilize CERNET and a resource-sharing consortium of major academic libraries. The National Cultural Information Resource Sharing Project, started in 2002, is another prominent project funded and administered by the Ministry of Culture. This project aims to establish a national cultural archival and distribution network through a 1-3-5 plan with 1 standing for a national center (the National Digital Library), 3 standing for 30-plus provincial sub-centers, and 5 standing for 5000-plus information network interconnections at the county, township, and community level. It is worth mentioning that all these large national projects were approved and funded by state-level departments (either the Ministry of Culture or the Ministry of Education) and were implemented by the subsidiaries of the two ministries at the provincial level. The Ministry of Culture relies on the national and provincial public libraries and cultural centers for content creation and contribution. The Ministry of Education relies on a couple dozen top national universities for content creation and contribution. The agencies and offices at the county and township level are rarely significant content creators and contributors; they are merely distributors whose responsibilities are to ensure the general public in the local communities has access to this information (Yu \& Yu, 2013).

\section{REFERENCES}

Boyce, J. I., \& Bert, R. B. (1995). Library outreach programs in rural areas. Library Trends 44(1), 112-128.

Chen, W., \& Wellman, B. (2009). Net and jet: The Internet use, travel and social networks of Chinese Canadian entrepreneurs. Information, Communication of Society 12(4), 525-547.

CNNIC. (2003). Semi-annual survey report on the development of China's Internet. Retrieved January 18, 2013, from http://www.CNNIC.net.cn

Feld, S. (1982). Social structural determinants of similarity among associates. American Sociological Review 47, 797-801.

Hu, L., \& Jiang, G. (2010). Oral history and native culture preservation: Our view of the oral history preservation projects at Tianzhu Tibetan Autonomous County. Retrieved December 28, 2012, from http://www.evergreeneducation.org/10confproceeds.php (胡立耘, 蒋国栋. 口述历 史: 拓展本土文化资源收藏的新途径-以天祝口述历史与文化实录项目为视点).

IFLA. (2009). The IFLA multicultural library manifesto. Retrieved January 18, 2013, from http:// archive.ifla.org/VII/s32/pub/MulticulturalLibraryManifesto.pdf

Internet. (n.d.) Wikipedia (English language site). Retrieved January 18, 2013, from http:// en.wikipedia.org/wiki/Internet

Qiu, F., \& Wang, Z. (2011). Development report on aid and support of NGOs to non-government funded libraries. Library and Information. http://www.xzbu.com/7/view-39548.htm (邱奉捷,王子舟. NGO 援建民间图书馆发展报告 (2011年) [J/OL]. 图书与情报).

Ristina, W. (1995). Across towns and across times: Library service to young people in rural libraries. Library Trends 44(1), 88-111.

Taylor, F., \& Latour, J. (2009). Contemporary glocal: Positioning a national mandate within a global context. Art Libraries Journal 34(1), 40-45.

Tianzhu County Bureau of Statistics. (2011). Tianzhu County Economic and Social Development Statistics Bulletin 2011. Retrieved December 28, 2012, from http://www.gstianzhu.gov.cn/ huarui/news/tzjj/tzjj/2012/510/12510101457DEJH7GG6EE367CI1G365.html (通渭县 统计局. 2011年天祝县国民经济和社会发展统计公报).

Tongwei County Bureau of Statistics. (2011). Tongwei County Economic and Social Development Statistics Bulletin 2011. Retrieved December 14, 2012, from http://www.gstj.gov.cn/doc/ ShowArticle.asp?ArticleID=13476. (通渭县统计局. 2011 年通渭县国民经济和社会发展统 计公报 $[\mathrm{EB} / \mathrm{OL}])$.

Uimonen, P. (2003). Networks of global interaction. Cambridge Review of International Affairs $16(2), 273-286$. 
Willems, J., \& Bossu, C. (2012). Equity considerations for open educational resources in the glocalization of education. Distance Education 33(2), 185-199.

Yu, L., \& Yu, B. (2013). The Top-Down Approach to Providing ICT Access to Rural Communities in China: Opportunities for Community Informatics. Library Trends, 62(1): 34-62.

Zhou, W., Dong, E. X., \& Zou, T. J. (2008). A school-library-centered community information resource sharing model and its impact on cultural life of rural communities in China. Paper presented at IFLA Annual Conference. Retrieved January 18, 2013, from http://www.ifla.org/IV/ ifla74/reports/106-Zhou_Dong_Zou-en.pdf

Wei Zhipeng 魏志鹏 is a librarian at the Gansu Provincial Library. He is also an editor of the Journal of Library and Information, a core national journal hosted by Gansu Library Association in Gansu Province, China. He is a volunteer for the Evergreen Education Foundation library programs.

Jiang Guodong 蒋国拣 is the principal of Tianzhu No. 1 High School. He joined Evergreen Education Foundation's programs in 2001. Since then he has led or participated in several school library outreach projects including Information and Communication Technologies Training Project and Tianzhu Oral History Project.

Niu Tuowen 牛托稳 is the principal of Tongwei No. 1 High School. Mr. Niu worked as the vice director of Tongwei Educational Bureau in the 1990s, where he was responsible for the implementation of both the Basic Education Project sponsored by the United Nations Children Foundation and the UNDP401 project. Since 2001, he has been actively involved in the implementation of several Evergreen Education Foundation rural library projects in Tongwei.

Tim Zou 邹际平 is access services librarian at the University of Arkansas Libraries, Fayetteville campus. He joined the Evergreen Education Foundation in 2007 as a librarian volunteer. He has continued to serve in this role since then. He is currently the chair of Arkansas ARKLink Resource Sharing Committee and chair of the ALA International Relations Round Table (IRRT) Preconference Committee.

Elaine Dong 董小芬 is database and metadata management librarian at the Florida International University. She has been a volunteer for the Evergreen Education Foundation since 2007. She has served on several committees of the Chinese American Librarians Association (CALA). 